\title{
El antagonista imprescindible: la construcción de la identidad nacional en la historiografía gallega
}

\section{The Essential Antagonist: the Construction of National Identity in the Galician Historiography}

\author{
Bruno Padín Portela \\ Universidad de Santiago de Compostela \\ bruno.padin@rai.usc.es
}

\section{Resumen}

En la construcción de las identidades nacionales es esencial el papel desempeñado por los enemigos externos y los enemigos internos. En el caso de Galicia, que es el que vamos a analizar, veremos que los traidores poseen una influencia mínima porque los enemigos más importantes se situarán fuera de Galicia. Se trata de Castilla y después España, antagonistas por antonomasia del pueblo gallego. Estudiaremos también la noción de antepasados gloriosos, muy útiles a la hora de proporcionar prestigio a la nación gallega, sobre todo en momentos de opresión o humillación. En este sentido, el mito celta, los suevos o los mártires serán figuras esenciales en el proceso de construcción de la identidad gallega. Analizaremos, por otro lado, la pervivencia de ciertos tópicos que desde el punto de vista histórico son insostenibles en el nacionalismo gallego actual.

\section{Palabras clave}

Nacionalismo gallego, BNG, mito celta, suevos, mártires, Castilla y España.

\begin{abstract}
The role played by external enemies and internal enemies is essential in the construction of national identities. In the case of Galicia, which we are going to analyze, we will see that the traitors have a minimal influence because the most important enemies will be located outside Galicia. It is Castile and then Spain, antagonist par excellence of the Galician people. We will also study the notion of glorious ancestors, very useful in providing prestige to the Galician nation, especially in times of oppression or humiliation. The Celtic myth, the suevos or the martyrs will be essential figures in the construction of Galician identity. On the other hand, we will analyze the survival of certain topics that from the historical point of view are unsustainable in current Galician nationalism.
\end{abstract}

\section{Key Words}

Galician Nationalism, BNG, Celtic Myth, Suevos, Martyrs, Castile and Spain. 


\section{Introducción}

El estudio del nacionalismo y de las historiografías nacionales ha alcanzado un gran desarrollo en los últimos años, siendo objeto de estudios individuales y de grandes proyectos colectivos, como el dirigido por Stefan Berger, Christoph Conrad y otros autores. ${ }^{1}$ A pesar de que no cabe duda de que el conocimiento histórico progresa gracias a las investigaciones empíricas, sin embargo, también es cierto que los elementos básicos del estudio de la nación y de la historiografía nacional no han cambiado desde hace muchos años, como puso de manifiesto el antropólogo Arnold van Gennep. ${ }^{2}$

Los elementos básicos que componen la nación siguen siendo los mismos en la bibliografía más reciente. ${ }^{3}$ Estos componentes son los conceptos de territorio y frontera, de lengua y cultura, de pueblo o raza, y de ordenamiento jurídico y soberanía nacional. Será con estos principios con los que se construyan los relatos de las historias nacionales que tienen, en esencia, una estructura común. Se trata de un relato lineal, con un protagonista exclusivo, el pueblo, que se mantiene sustancialmente igual a lo largo de todo el devenir histórico. Esto fue así en la historiografía del siglo XIX, y también lo será en la historiografía gallega que analizaremos a continuación.

Para comprender la historiografía que será objeto de nuestro estudio debemos tener en cuenta que no nos hallamos ante una historiografía que alcanzase su consagración como historia oficial de un Estado-nación, como le ocurrió a la historiografía española, francesa o alemana, sino de lo que podríamos llamar una historiografía reactiva o subalterna. Si deseamos entender a los historiadores regionalistas y nacionalistas gallegos podría parecer que tendría sentido comparar sus relatos con los de otras regiones de Europa que en determinados momentos aspiraron a constituirse como naciones o que fueron reinos en el pasado, como en el caso de Escocia. Sin embargo, esto no será así porque el referente casi obsesivo de los historiadores gallegos va a ser siempre España y la historia de España, como de hecho analizaremos. Cuando denominamos a esta historiografía como subalterna utilizamos el

\footnotetext{
${ }^{1}$ Ver S. Berger y C. Conrad, The Past as History. National Identity and Historical Consciousness in Modern Europe (Basingstoke: Palgrave Macmillan, 2015), un libro que forma parte de una serie de siete volúmenes, entre los que cabe destacar de interés para nuestro tema los tomos 3, S. Berger y C. Lorenz (eds.), The Contested Nation. Ethnicity, Class, Religion and Gender in National Histories, 2008; el tomo 5, T. Frank y F. Hadler (eds.), Disputed Territories and Shared Pasts. Overlapping National Histories in Modern Europe, 2011; y el tomo 6, S. Berger y C. Lorenz (eds.), Nationalizing the Past. Historians as Nation Builders in Modern Europe, 2010, todos ellos publicados en la misma editorial.

${ }^{2}$ Traité comparatif des nationalités (París: Payot, 1921), publicado justo después del final de la I Guerra Mundial, que fue el proceso histórico que dio lugar en Europa a la creación del mayor número de nuevas naciones, y que curiosamente va a ser el momento en el que se consolidará el nacimiento del nacionalismo gallego, ya había puesto de manifiesto como todos los nacionalismos tienen muchos caracteres en común. Como también haría poco después J.T. Delos, El problema de la civilización. La nación. I. Sociología de la nación. II. El nacionalismo y el orden del derecho (Buenos Aires: Editorial Desclée, 1948). Y un poco más tarde G. Weill, La Europa del siglo XIX y la idea de nacionalidad (México: UTEHA, 1961).

${ }^{3}$ Como es el caso de autores como A.D. Smith, Nacionalismo y Modernidad (Madrid: Itsmo, 2000), y A. Hastings, La construcción de las nacionalidades. Etnicidad, religión y nacionalismo (Madrid: Cambridge University Press, 2000).
} 
término en el sentido que le dio Dipesh Chakrabarty. ${ }^{4}$ El subalterno, de acuerdo con esta teoría, es una persona o un grupo que ha sufrido un proceso de colonización y de negación de su identidad, y que intenta asumir y reconstruir una identidad nueva, pero lo hace, como no podía ser de otra manera, partiendo de la situación en la que vive, que es la situación de dominación, lo que explica el mimetismo, según Chakrabarty, entre el colonizador y el colonizado, algo que como veremos, en otro nivel, está presente en los historiadores gallegos.

La historiografía gallega que estudiamos no solo no fue una historiografía consagrada políticamente en un sistema educativo estatal, sino que en muchos casos ni siquiera sus historiadores tuvieron formación académica, aunque el principal de ellos, Manuel Murguía, sin duda la tuvo porque se formó como archivero en la Escuela Superior de Diplomática de Madrid. La carencia de la formación académica y el escaso nivel de profesionalización de estos historiadores puede hacer que en algún caso se desdibujen los límites entre la historia y la ficción, pero esto tampoco sería algo exclusivo de la historiografía gallega, ni se debería exclusivamente a su situación de historiografía subalterna, sino que es propio también de toda la historiografía del siglo XIX, en la que los límites entre la historia y la novela histórica y otro tipo de ficciones literarias son muy confusos, como puso de manifiesto Brian Hamnett. ${ }^{5}$

Es bien sabido que Leopold von Ranke, que se había formado como filólogo clásico, decidió orientarse hacia el estudio de la historia después de haber leído las novelas de Walter Scott, y es un hecho conocido que algunos historiadores del siglo XIX cultivaron a la vez el género historiográfico y la novela histórica paralelamente. Esto ocurrirá igualmente en la historiografía gallega, en historiadores sin formación académica como Benito Vicetto, pero también en el historiador gallego de finales del siglo XIX y principios del XX con mayor formación técnica, como lo fue el canónigo Antonio López Ferreiro, autor de una monumental Historia de la Santa A.M. Iglesia de Santiago de Compostela en once volúmenes, y a su vez de novelas históricas. Los límites entre historia y ficción, tanto en este caso como en los demás, tal vez no desmerezcan la calidad de la obra historiográfica, pero pueden hacerse muy confusos cuando una determinada corriente historiográfica se convierte, además, en una doctrina política que tiene como fin crear un movimiento de orientación nacionalista, como ocurrió con muchas historiografías de los siglos XIX y XX, entre las que se encuentra la historiografía regionalista y nacionalista gallega.

Los historiadores gallegos, como Vicetto o Murguía en el siglo XIX, o Vicente Risco en el XX, intentaron movilizar al pueblo gallego y avivar su conciencia política. En sus obras ese pueblo a veces es denominado con el término raza, que si bien no tenía en el siglo XIX el mismo sentido que luego haría tristemente famoso el nazismo o el racismo blanco norteamericano, sin embargo, sí que está directamente relacionado con

\footnotetext{
4 Provincializing Europe. Postcolonial Thought and Historical Difference (Princeton: Princeton University Press, 2000). Sobre este concepto también puede ser interesante la consulta del libro de María José Vega, Imperios de papel. Introducción a la crítica postcolonial (Barcelona: Crítica, 2003).

${ }^{5}$ The Historical Novel in Nineteenth-Century Europe. Representations of Reality in History and Fiction (Oxford: Oxford University Press, 2011). Puede ser útil, asimismo, el libro de T. Koditschek, Liberalism, Imperialism, and the Historical Imagination. Nineteenth-Century Visions of a Greater Britain (Cambridge: Cambridge University Press, 2011).
} 
la idea de desigualdad y la idea de superioridad. ${ }^{6} \mathrm{Y}$ es a partir de esa misma idea como se establecen los sentimientos colectivos de identificación con el pueblo propio y de odio con el pueblo rival o los demás pueblos, tal y como puso de manifiesto magistralmente para la época victoriana Peter Gay. ${ }^{7}$ Los historiadores gallegos de los que vamos a tratar parten de la existencia de un sentimiento de inferioridad que además está interiorizado por los propios gallegos como sentimiento de autodesprecio, y por esa razón es comprensible que intentasen sustituirlo por otro sentimiento de superioridad que haría que el pueblo gallego, a pesar de su situación subalterna en la historia, aparezca muchas veces como un pueblo superior, ya sea por el nivel alcanzado en su literatura medieval, por sus virtudes heroicas en diferentes episodios, o por su capacidad de organización económica y social. Tanto Murguía en el siglo XIX como Vicente Risco en el XX desarrollaron una curiosa asociación entre el pueblo gallego como celta y el pueblo español nunca bien definido, que en el segundo de estos autores aparece claramente como un pueblo semita o próximo a los semitas. Será a partir de estas ideas básicas como desarrollaremos el estudio que a continuación se ofrece.

Aprovecharemos, pues, esta oportunidad para revisitar algunas de las obras de síntesis más relevantes de la historiografía gallega contemporánea. Nos centraremos en este lapso de tiempo porque son las más relevantes en el proceso de construcción de la identidad gallega. Hubo que esperar hasta inicios del siglo XVII para que apareciese la idea de una historia de Galicia, siendo algunos pocos los que se atrevieron a intentar llevarla a cabo. Tal y como ha señalado Ofelia Rey, solo una de las crónicas, la de Huerta y Vega, llegó a publicarse, antes de que en el siglo XIX hubiese otro intento de plasmar en una síntesis histórica el pasado gallego. ${ }^{8}$

No cabe duda de que el Sempre en Galiza de Castelao no es en sentido estricto una historia de Galicia al uso como lo son las de Vicetto o Murguía, pero su importancia en la configuración de la ideología nacionalista gallega justifica totalmente su inclusión en estas páginas. Lo mismo sucede con la obra de Risco, ya que a pesar de que escribió una obra de síntesis es necesaria la alusión a otros textos básicos como la Teoría do nacionalismo galego. Será pertinente, asimismo, la mención puntual de otros intelectuales, literatos e historiadores en el transcurso del trabajo, por su influjo en esa corriente política e ideológica que en la Galicia contemporánea logró asentar el proceso de toma de conciencia del carácter diferencial de Galicia, llamado galleguismo.

\section{El celtismo}

Es necesario, antes de repasar algunos de los mitos más importantes de la historiografía gallega, referir la relevancia que el celtismo tuvo como mito fundador de Galicia, ya que va a ser el punto de partida a través del cual se vertebre toda la identidad gallega y, consecuentemente, todos los episodios y personajes representativos en esta mitología. Lo cierto es que los nacionalismos necesitan sus lugares comunes. Los tuvo

\footnotetext{
${ }^{6}$ Como señala T. McCarthy, Race, Empire, and the Idea of Human Development (Cambridge: Cambridge University Press, 2009).

${ }^{7}$ P. Gay, The Cultivation of Hatred. The Bourgeois Experience: Victoria to Freud (Londres: W.W. Norton \& Company, 1993).

${ }^{8}$ Sobre este tema ver O. Rey Castelao, “As historias de Galicia na Idade Moderna”, en I. Dubert (ed.), Historia das historias de Galicia (Vigo: Xerais, 2016), 241-270.
} 
la historiografía española y los tendrá la gallega. Suele ser habitual que los historiadores tiendan a buscar en la Antigüedad los orígenes de su nacionalidad, y lo harán a través de ciertos antepasados gloriosos, cuanto más antiguos mejor, lo cual tampoco es un fenómeno aislado de la historiografía gallega sino que es común a toda la europea desde el Renacimiento. Será precisamente ahí, en los tiempos más remotos de la historia de Galicia, donde se rastreen las verdaderas esencias que acabarán conformando el verdadero ser nacional.

Pero antes de comenzar con el tema del celtismo conviene realizar unas consideraciones previas para las cuales nos será especialmente útil el modelo que José Carlos Bermejo elaboró en torno a la noción de "antepasados imaginarios".9 Utilizó Bermejo para ello, en buena medida, la idea de metáfora del parentesco de Alexander Demandt así como uno de los cuatro tipos de relato que Jörn Rüsen, un filósofo de la historia alemán, sistematizó. ${ }^{10}$ Entre las cuestiones a las que se pueden asociar las metáforas del parentesco se encuentra la noción de antigüedad, que es la que nos va a interesar. Es relevante porque, como dice Bermejo, esa idea en muchas ocasiones es sinónimo de prestigio, puesto que el valor de un objeto, una cultura o una lengua es mayor cuanto mayor sea su permanencia en el tiempo. ${ }^{11}$ Manuel Murguía testimonia esta idea al relatar el proceso de asentamiento celta: "Lo que si puede asegurarse es que la mayor parte de los nombres de montañas, rios y lugares de Galicia llevan nombres arianos [...] si los celtas no fueron los primeros que ocuparon nuestro suelo, fueron sí sus más antiguos y afortunados poseedores". ${ }^{12}$ Ese prestigio derivado de la Antigüedad será clave para entender el papel de los antepasados imaginarios en una época donde es necesario reivindicar un pasado glorioso en contraposición con un presente caracterizado por la humillación y la opresión.

En cuanto a la tipología del relato, distinguía Rüsen entre el tradicional, el ejemplar, el crítico y el genético, de los que, para nuestro trabajo, nos interesará el primero de ellos. Se caracteriza el relato tradicional porque recuerda a los orígenes, que explican las formas de vida presentes. La identidad se logra mediante la autoafirmación de los modelos culturales de autoanálisis. En el relato tradicional domina el sentido de la eternidad. ${ }^{13}$ ¿Qué es lo que se pretende? Como veremos, mostrar la continuidad e inmutabilidad de un territorio y sus habitantes desde, en este caso, más de dos milenios, lo que revela una visión de la historia claramente esencialista.

David Lowenthal argumentó que el pasado da validez a las actitudes y acciones del presente afirmando su semejanza con las anteriores. El precedente histórico legitima lo que hoy existe y lo hace de dos formas diferentes: conservando y restaurando. La conservación recurriría a la continuación de prácticas que supuestamente datarían de tiempos inmemoriales y, en caso de que hubiese cambios, serían estos superficiales e inconsecuentes. El segundo modo de validación sería la restauración de valores e instituciones perdidas o transformadas. La identificación con un pasado nacional sirve

\footnotetext{
9 J.C. Bermejo Barrera, "Los antepasados imaginarios en la historiografía gallega", Cuadernos de Estudios Gallegos, 103 (1989): 73-91.

${ }^{10}$ J. Rüsen, “Historical Narration: Foundation, Types, Reason”, History and Theory, 26 (1987): 87-97.

${ }^{11}$ J.C. Bermejo Barrera, "Los antepasados", 76.

${ }_{12}^{12}$ M. Murguía, Historia de Galicia, vol. 1 (Lugo: Imprenta de Soto Freire, 1865), 392.

13 J. Rüsen, "Historical Narration", 90-91.
} 
como un valor seguro contra la subyugación o sirve de refuerzo a una nueva soberanía. Es así que el pasado remoto legitima y fortalece el orden presente frente a los contratiempos y corrupciones posteriores. Este regreso al pasado suele ser más habitual en los tiempos difíciles, ya que la capacidad de recordar nuestro pasado e identificarnos con él ofrece, según Lowenthal, significado, finalidad y valor a nuestra existencia, lo cual se aprecia muy bien si hablamos de la historia de Galicia. ${ }^{14}$

Esta determinada concepción de la historia de Galicia, que es también, como veremos, el paradigma dominante en la historiografía española, debe ponerse en relación con el concepto de nación. Naturalmente no realizaremos un análisis exhaustivo de dicho término, pero consideramos pertinentes unos breves comentarios sobre ese concepto del que, como es sabido, no existe una definición unánimemente aceptada entre los especialistas que se dedican a su estudio. Seguimos de nuevo, en este punto, a Bermejo, cuando distingue dos teorías acerca de lo que puede ser una nación: las teorías ontológicas y realistas y las teorías lingüísticas y consensualistas. ${ }^{15}$ Las primeras afirman que las naciones existen in re, dividiéndose a su vez en dos tipos: las teorías esencialistas o estáticas y las teorías dinámicas. Las esencialistas, también llamadas organicistas, y en las que se inserta la visión dominante de la historia de Galicia, parten de que las naciones y los pueblos asociados a ellas son los sujetos de las "historias nacionales", manteniendo unas características comunes, su identidad, a lo largo de todo el proceso histórico. Las teorías ontológicas de tipo dinámico proponen, en cambio, que una nación nunca es el punto de partida en un proceso histórico, sino su conclusión. ${ }^{16}$

En cuanto a las teorías lingüísticas y consensualistas, que tuvieron su primer defensor en Ernest Renan y su libro ¿Qué es una nación?, definen a la nación como un proyecto de futuro y no como una esencia que se prolonga en el tiempo desde el pasado. La existencia de una nación viene dada por la voluntad y el consenso de sus ciudadanos. No se trata de una realidad inmutable o indiscutible. Sostienen estos autores, entre los que también se encuentran Benedict Anderson, Anthony Smith o Ernest Gellner, que el proceso de construcción de una nación se lleva a cabo gracias a una mezcla entre instrumentos externos, que configuran el Estado-nación, e instrumentos internos, básicamente la lengua y la educación nacional. ${ }^{17}$

Si hubo una figura dominante en el galleguismo del siglo XIX esa fue, sin duda, Manuel Martínez Murguía. Se formó en Madrid, en la Escuela Superior de Diplomática, donde adquirió sus habilidades básicas como historiador y tuvo una etapa como redactor en periódicos como La Iberia, Las Novedades o El Correo Universal. De vuelta a Galicia se entregó a la redacción de su obra magna, la Historia de Galicia, publicada en cinco tomos entre los años 1865 y 1913. Situó Murguía a la nación como el sujeto histórico principal, siendo el resultado de la combinación entre una raza y un territorio del que nacería el Volkgeist gallego. De hecho, es posible que la ruptura decisiva en la configuración de la historia de Galicia como historia nacional la ofreciese Murguía.

\footnotetext{
${ }^{14}$ D. Lowenthal, El pasado es un país extraño (Madrid: Akal, 1998), 79-80.

15 J.C. Bermejo Barrera, La tentación del rey Midas. Para una economía política del conocimiento (Madrid: Siglo XXI, 2015), 146.

${ }^{16}$ Ibid., 146-147.

${ }^{17}$ Ibid., 148-149.
} 
Habría dado este autor el paso decisivo de cara a la fundamentación del hecho diferencial gallego y su Historia de Galicia, de acuerdo con Ramón Máiz, es el intento más serio y militante de legitimación histórica de Galicia. ${ }^{18}$ Impregnado de un fuerte historicismo, romperá con la metodología de Vicetto al emplear por primera vez prácticas como el empleo de documentación o la visita a los archivos, lo que desde el punto de vista metodológico le confirió al texto murguiano verosimilitud de cara a la construcción de la conciencia nacional gallega. ${ }^{19}$ Concebía Murguía la historia de la humanidad, asimismo, y en consonancia con las tendencias historiográficas españolas y europeas, como un devenir prefijado y regido por leyes dictadas por la divinidad. Así lo reflejaba en el Discurso Preliminar, tan del gusto de la época:

\begin{abstract}
Camina la humanidad por ocultos senderos el cumplimiento de sus destinos y obedece á la ley providencial que la rige, hasta en los momentos en que nos parece mas exenta de su influjo misterioso [...] Nació el hombre y las leyes de la naturaleza hicieron de él un ser progresivo; de aquí que la sociedad haya tenido tambien su infancia en la cual, las ideas mas claras se presentaron al espíritu humano confusamente, sin que le fuese dado entonces alcanzar á comprenderlas en toda su estension y por lo mismo á formularlas. El hombre tenia un destino que cumplir sobre la tierra y hácia ese fin marchaban, desde el momento en que vieron la luz, los individuos y los pueblos. $^{20}$.
\end{abstract}

En ese decurso histórico regido por la providencia los celtas ocupan el papel central que se le suele tener reservado al antepasado que mejor va a representar las esencias propias de un determinado ser nacional. El recurso al celtismo para explicar el componente étnico de Galicia va a ser habitual en la obra de Alfredo Brañas, Castelao o Vicente Risco, por referirnos solo a algunos. Brañas, un catedrático de Economía Política y Hacienda Pública de la universidad compostelana, incorporado al regionalismo procedente de los ambientes católicos más conservadores de Santiago, sostiene: "El país gallego ha constituido, desde los tiempos más remotos, un círculo social independiente dentro de la nacionalidad española", y a pesar de haber estado dominado "sucesivamente por celtas, suevos, romanos, godos y árabes", pudo conservar "á través de los siglos la fisonomía especial á cuya formación contribuyeron celtas y suevos, los únicos pueblos, las dos únicas razas que constituyeron la personalidad, el carácter y el tipo de los habitantes de Galicia". ${ }^{21}$

\footnotetext{
18 R. Máiz, O rexionalismo galego. Organización e ideoloxía (1886-1907) (Sada: Ediciós do Castro, 1984), 46.

${ }^{19}$ Ibid., 47.

${ }^{20}$ M. Murguía, Historia de Galicia, vol. 1 (Lugo: Imprenta de Soto Freire, 1865), 1-3. La semejanza con el inicio de la Historia general de España de referencia del siglo XIX, la de Modesto Lafuente, es evidente. Dice Lafuente: "La humanidad vive, la sociedad marcha, los pueblos sufren cambios y vicisitudes, los individuos obran. ¿Quién los impulsa? ¿Es la fatalidad? ¿Hemos de suponer la sociedad humana abandonada al acaso, ó regida solo por leyes físicas y necesarias, por las fuerzas ciegas de la naturaleza, sin guia, sin objeto, sin un fin noble y digno de tan gran creación? [...] Por fortuna hay otro principio mas alto, mas noble, mas consolador, á que recurrir para esplicar la marcha general de las sociedades, la Providencia, que algunos no pudiendo comprenderla han confundido con el fatalismo [...] encadenamiento de sucesos con que el género humano va marchando hacia el fin á que ha sido destinado por el que le dió el primer impulso y le conduce en su carrera", Historia general de España, vol. 1 (Madrid: Establecimiento Tipográfico de Mellado, 1851), 1-2.

${ }^{21}$ A. Brañas, El regionalismo. Estudio sociológico, histórico y literario (Barcelona: Jaime Molinas editor, 1889), 203. Sobre Brañas ver el libro de R. Máiz, Alfredo Brañas. O ideario do rexionalismo católicotradicionalista (Vigo: Galaxia, 1983), y el de J. Beramendi, Alfredo Brañas no rexionalismo galego (Santiago de Compostela: Fundación Alfredo Brañas, 1998).
} 
Castelao se expresa de modo similar: "Galiza ten un carácter étnico proprio, que provén dos povoadores celtas, que constituiron o seu primeiro orgaismo habitual e territorial, podendo afirmarse que todos cantos alí chegaron dispois, procedían do mesmo tronco e repetían o mesmo sangue". ${ }^{22}$ Por otra parte, establece Castelao nítidamente la sucesión de pueblos que tienen en común el componente celta, en contraposición con otras razas que habitan también en la Península. Siguiendo lo dicho por Portela Valladares, un antiguo político gallego de principios del siglo XX, dice:

\begin{abstract}
Eisiste en Galiza unha homoxeneidade de carácter, tan secularmente autóctono, tan contrario â alma castelán, que a miúdo caemos en tentacións antipáticas, tales como a de proclamar que nós somos ários e os demáis semitas. Con todo séxanos permitido decir con Portela Valladares: "Os confusos lindeiros de raza destácanse en Galiza de rara maneira, porque celtas, suevos, normandos, pelengrinantes, cantos alá foron veñen d-un tronco omún, repiten o mesmo sangue, coma o repiten os iberos, os fenicios, os árabes e bereberes, os almohades e os almorávides, n-outras zonas da Penínsua. En canto é posible, induvidablemente, poseímos unidade etnográfica". ${ }^{23}$
\end{abstract}

Volviendo a la concepción histórica de Murguía deberíamos llamar la atención acerca de la idea de héroes fundadores, encarnada por el mito celta. Sin embargo, existe un problema, y es que como ha puesto de manifiesto Bermejo ${ }^{24}$ un héroe solo puede fundar una casta o una ciudad pero no un pueblo, por eso Murguía habla de pueblo celta, padre del pueblo gallego y fundador de su cultura, razón por la cual tiene necesariamente que ser objeto privilegiado de la historia de Galicia: "Los iberos y los celtas fueron, segun todas las probabilidades, los primeros pobladores de España, tocando á los iberos las tierras llanas, y á los celtas las altas, y entre ellas está Galicia, en la cual todavia acampan sus descendientes". ${ }^{25}$ El componente celta pasa a ser con Murguía el definidor que aporta la sólida base sobre la que se erige, tanto la garantía de una nobleza como la de una superioridad nacional que, en último término va a resultar muy útil a la hora de reforzar la dignidad de la patria que ha sido secularmente humillada.

La acción política del sujeto narrativo, esto es el pueblo gallego, se orienta siguiendo los comentarios de Bermejo, en torno a los conceptos de gloria, orgullo y encomio, o en torno a los de derrota, humillación y desprecio. Crea Murguía al entrar en el ámbito de estos términos retóricos un metarrelato épico de la historia de Galicia que tendría que acabar en una victoria política final. Ahora bien, ¿cómo es posible entender que un pueblo subordinado políticamente sea al mismo tiempo políticamente glorioso? Pues recurriendo a la descripción de episodios épicos que veremos como el del Monte Medulio, el reino suevo o la Revolta Irmandiña. Los antepasados, que en esta ocasión están encarnados en el celta arquetípico, fueron superiores en el origen pero también vencidos gloriosamente. Es en esa gloria inmortal, unida a la diferencia y superioridad que proporcionaba la naturaleza céltica de lo gallego, donde residiría la esperanza de una situación futura en la que se podría volver a esas anheladas grandezas perdidas. Se trata de una concepción duradera y que Bermejo definió como "esplendor de la

\footnotetext{
${ }^{22}$ A. Castelao, Sempre en Galiza (Madrid: Akal, 1977), 446.

${ }^{23}$ Ibid., 260-261.

${ }^{24}$ J.C. Bermejo Barrera, ¿Para que serve a historia de Galicia? (Santiago de Compostela: Lóstrego, 2007), 114

${ }^{25}$ M. Murguía, Historia de Galicia, vol. 1, 6.
} 
miseria", al ponerlo en relación con el discurso histórico gallego actual, donde sea o no nacionalista, se argumenta evocando una situación de marginación política y atraso económico que habría caracterizado al pueblo gallego, así como un supuesto esplendor cultural difícil de hacer compatible con la situación histórica real. ${ }^{26}$

La raza semítica es situada por los ideólogos más importantes del galleguismo político como punto de referencia negativo que cohesiona los antivalores del ser nacional en contraposición con el mito central del imaginario nacionalista, que es el celto-suevo. Teniendo en cuenta esta tesis, es claro que entre los objetivos primordiales se situaría salvar la pureza céltica. Quizás el autor que más acerbamente defendió estos postulados racistas fue Vicente Risco. Establece Risco, en su Teoría do nacionalismo galego, una meridiana división de España en dos partes que nos ahorra cualquier tipo de comentario adicional:

\begin{abstract}
Podemos dividir a Hespaña en duas partes, das que a unha pertence craramente á Europa ya outra pertence á Africa. Unha liña que seguise o curso do Douro e mais do Ebro, sopararía a unha da outra; a que fica car'ó Norte, podémoslle chamar porén, Euriberia, y-a que fica car’ó Sul, Afroiberia. É na Euriberia onde se sinten fortemente as arelas nacionalistas. Cataluña e Vasconia non consentirán nunca en vérense privadas de todo, das suas vellas libertades. Fóronas defendendo unha a unha, contr'aa soberanía agresiva de Castela, vertendo o seu sangue en todal-as guerras civís, sosteñendo o pantasma do Calrismo, no que vían a salvagarda d'elas, e inda se foron quedando co seu direito foral, e mais con algunha independencia económeca... ${ }^{27}$
\end{abstract}

Risco escribió, además, una Historia de los judíos, publicada en 1944, cuando seis millones de judíos estaban siendo aniquilados masivamente por el régimen alemán, y que, por cierto, suele ser muy poco citada, no sabemos si en la línea de administración del silencio que se le aplicó al propio Risco por parte del nacionalismo gallego de la segunda mitad del siglo XX, inclinado claramente a la izquierda por dos razones: su traición en el año 1936 al ponerse del lado sublevado y su deriva hacia posiciones de extrema derecha que se aprecia en la década de los treinta. Incluye Risco en este libro todos los tópicos medievales que tradicionalmente se le asignaron a los judíos, como su supuesta participación en la "pérdida de España" de 711 ayudando a los musulmanes como "quinta columna". A esto habría que añadir el hecho de que, según Risco, los judíos se escondían detrás de todos los ataques contra el catolicismo: "Es demasiado frecuente que cuando hay algún ataque contra la Iglesia o contra personas eclesiásticas o católicas, algún proceso o escándalo de esta clase, aparezca complicado en ello algún judío". ${ }^{28}$

Sin embargo, Risco plantea que los judíos deben existir y es providencial su conservación porque suponen un "testimonio viviente de la Palabra de Dios, en su tradición, en su historia, en las Escrituras que han conservado. Por eso es digno de un especial respeto". ${ }^{29}$ No niega Risco que se le permita el culto que los judíos profesaban en las sinagogas, sino que simplemente lo que habría que hacer es evitar que se extendiese: "el proselitismo de los judíos debe ser rigurosamente prohibido", además de

\footnotetext{
${ }^{26}$ J.C. Bermejo Barrera, ¿Para que serve?, 139 y 141.

${ }^{27}$ V. Risco, Teoría do nacionalismo galego (Ourense: Imprenta de La Región, 1920), 12.

${ }^{28}$ V. Risco, Historia de los judíos. Desde la destrucción del templo (Valladolid: Maxtor, 2005), 361.

${ }^{29}$ Ibid., 230.
} 
subrayar la importancia de mantener pura la raza, para lo que sería esencial "poner obstáculos que impidan los matrimonios mixtos, y hasta restringir las relaciones privadas entre cristianos y judíos". ${ }^{30}$

Es claro, por tanto, que el nacionalismo gallego se integra dentro de las corrientes racistas predominantes del siglo XIX. Se pone de manifiesto de este modo, en fin, que cada ideología va a amoldar a sus intereses el tipo de antepasado glorioso con el que se quiere emparentar, y de la mano de esa decisión se elaborarán toda una serie de medidas encaminadas a preservar la pureza de cada una de las razas. En el caso que nos ocupa, el elemento céltico es la clave de bóveda sobre la que se construye toda la identidad gallega.

\section{El monte Medulio}

Como hemos visto es lógico que el nacionalismo gallego buscase en los orígenes el comienzo de su pasado glorioso. Es ahí precisamente, en la Antigüedad, donde veremos las primeras manifestaciones del genio del carácter nacional, asociado esencialmente a las luchas contra el invasor romano. Dentro de estas batallas, que van a ser siempre en nombre de la independencia de Galicia, destaca sobre todas la que tuvo lugar en el monte Medulio.

Tiene que ver esta tendencia hacia la veneración de lo antiguo con un proceso consistente, según Bermejo, en un desplazamiento de prestigio de las fuentes bíblicas y los textos hagiográficos hacia el de los autores grecolatinos, a los que se les dotará de una autoridad indiscutible. ${ }^{31}$ Esto es así porque Plinio o Silio Itlálico posibilitan un prestigio derivado de la época en la que escriben, es decir, según esta idea lo más antiguo es lo verdadero y, por otra parte, lo que redactan lo hacen desde el lado de los opresores, lo cual eleva el mérito de los oprimidos.

Un historiador suele reconstruir el pasado a través de documentos o monumentos. Entre las categorías de documentos que cabe encontrarse en una reconstrucción que siempre es fragmentaria se encuentran las fuentes literarias, sobre todo en los periodos antiguo y medieval. Podríamos decir, como ha indicado Bermejo, que los documentos no hablan de nada, ya que los que en realidad hablaron fueron los seres humanos que los escribieron o que fabricaron los objetos que los arqueólogos estudian. ${ }^{32}$ Las fuentes literarias son obra de griegos y romanos que en este caso conquistan Gallaecia y que se insertan dentro de su discurso etnográfico, por lo que hablan más de la identidad del griego o el romano, definida por su contraste con el bárbaro. ${ }^{33}$ Esta reflexión es pertinente porque advierte sobre la necesidad de realizar una correcta lectura hermenéutica.

\footnotetext{
${ }^{30}$ Ibid., 230.

${ }^{31}$ J.C. Bermejo Barrera, "Los antepasados imaginarios", 81.

${ }^{32}$ J.C. Bermejo Barrera y P.A. Piedras Monroy, Genealogía de la historia. Ensayos de historia teórica III (Madrid: Akal, 1999), 156.

${ }^{33}$ Ver sobre este tema los trabajos de J.C. Bermejo Barrera, ¿Para que serve?, 121-122, e Id., Mitología y mitos de la Hispania prerromana, II (Madrid: Akal, 1986).
} 
Naturalmente hoy en día es insostenible creer que en el Monte Medulio se encontraban gallegos luchando por la independencia. La idea era atractiva y podía sugerir y en efecto sugirió una analogía entre el poder romano y el Estado centralizador encarnado en el reino de Castilla y después en España, ambos opresores del ser nacional y empeñados secularmente en cercenar los recursos y la identidad del pueblo gallego. Pero de ningún modo tiene validez el argumento del Medulio porque equivaldría a afirmar, cayendo en un evidente anacronismo, que en el caso español Viriato o Sertorio habían sido libertadores de España en una época en la que ni el concepto de Galicia ni el de España existía. ${ }^{34}$

Con este episodio podemos ver claramente el modelo interpretativo al que responde la historiografía gallega. Se entremezclarían dos rasgos, el esencialismo y el invasionismo, al que habría que añadir otro más, que nos lo ofrece Murguía al hablar del Monte Medulio. Dice Murguía: "asi le fué fácil á Bruto ir venciendo poco á poco y separados, á los que juntos hubieran hecho huir de nuevo las águilas de Roma". Pone de manifiesto, pues, que el individualismo contribuyó decisivamente a la derrota, idea sobre la que insiste un poco más adelante: "En la presente ocasion, como en otras muchas, el mayor enemigo de estos pueblos estuvo siempre en ese instinto de fiera individualidad que [...] les ha dejado siempre entregados á los propios esfuerzos y por lo mismo fáciles á los mayores contratiempos". ${ }^{35}$ Nos encontraríamos, en realidad, ante el mismo esquema que dominó la historiografía española desde que el jesuita Juan de Mariana escribiese su Historia general de España en las postrimerías del siglo XVI y hasta la primera mitad del siglo XX, donde sobresalió la Historia de España llevada a cabo por diversos autores bajo la dirección de Ramón Menéndez Pidal. ${ }^{36}$

\section{Los suevos}

El siguiente eslabón en el proceso de construcción de la identidad gallega habrían de ser los suevos. Tanto la historiografía portuguesa como la gallega recurrieron al reino suevo con fines, como parece evidente, reivindicativos. El origen de esa identificación sueva por parte de los autores gallegos, que son los que nos interesan en este momento, deberíamos buscarla, de acuerdo con Pablo C. Díaz, en la proclama que Antolín Faraldo Asorey redactó con motivo de la "Junta provisional de Gobierno de Galicia", en el contexto de la Revolución de 1846 comandada por Miguel Solís contra el gobierno de Narváez. ${ }^{37}$ En el texto de Faraldo, que como ha indicado Beramendi fue quien introdujo el recurso sistemático a la historia como criterio de verdad y fuente de legitimidad

\footnotetext{
${ }^{34}$ Sobre el concepto de España ver J. Álvarez Junco, Mater dolorosa. La idea de España en el siglo XIX (Madrid: Taurus, 2001), 35-45.

${ }^{35}$ M. Murguía, Historia de Galicia, vol. 2 (Lugo: Imprenta de Soto Freire, 1866), 226.

36 Acerca del esencialismo (y el problema que este término pueda ocasionar), el invasionismo y la desunión, ver, para la historiografía española, los siguientes trabajos: F. Wulff y G. Cruz Andreotti, "On Ancient History and Enlightenment: Two Spanish Histories of the Eighteenth Century", Storia della Storiografia, 23 (1993), 80 (75-94); F. Wulff, "La Antigüedad en España en el siglo XIX: seis historias de España”, en M. Belén y J. Beltrán (eds.), Arqueología fin de siglo. La arqueología española de la segunda mitad del siglo XIX (Sevilla: Universidad de Sevilla, 2002), 127-128.

${ }^{37}$ P.C. Díaz, El reino suevo (411-585) (Madrid: Akal, 2011), 19.
} 
nacional en la filosofía básica del galleguismo, ${ }^{38}$ podemos leer algunos de los tópicos más recurrentes en la relación entre Galicia y España: la consideración de la primera como colonia de la segunda, la caracterización de Galicia como un pueblo humillado y abatido por el tirano Estado español o la exhortación a elevar a Galicia en el alto lugar que estaba llamado a ocupar el antiguo reino de los suevos, que es la forma en que se concluye la proclama.

Murguía, de nuevo, influirá decisivamente por encima de cualquier literato o poeta en la idealización mítica del reino suevo. La validez del modelo murguiano se explicaría, de acuerdo con Bermejo, en base a dos razones. Por un lado, como cualquier intento parcial por reconstruir la realidad sería parcialmente verdadero, y en segundo lugar, por las circunstancias adversas al autogobierno gallego desde la época que escribe hasta 1978. En esas circunstancias dicha tradición historiográfica estuvo unida a una determinada militancia política que la mantuvo viva al margen de la tradición académica. ${ }^{39}$ La contribución esencial que los suevos habían proporcionado a Galicia consistía en el pensamiento murguiano, como señaló Ramón Máiz, en dos cuestiones. Por un lado revitalizando el debilitado sustrato céltico con su componente germánico y, en segundo lugar, recuperando la independencia perdida por Galicia durante la ocupación romana. ${ }^{40}$ Así lo puso de manifiesto:

\begin{abstract}
Que si más de ciento setenta años de dominación sueva pudo formar un carácter, los ciento treinta de la goda, más poderosa, más pacífica, más adelantada aunque no tan directa, debían haberlo borrado por completo á tener el vigor é intensidad, que si hemos de atender á los hechos, pudiera presumirse y aun darse por indubitable. Mas no fué así.- La gente sueva fué vencida pero no anulada, ni dispersa. Siguió en el mismo territorio, siguió poseyendo y siendo la misma al lado de la población celto-gallega con la cual se había mezclado por completo y hecho otra como ella [...] Costumbres, supersticiones, poesía, ley, lenguaje, cuanto se refiere al mundo real y al de la imaginación, cuanto toca á la organización de la familia y de la sociedad y se conserva todavía entre nosotros, lleva á menudo el sello de un cierto predominio germánico, por cuya eficacia tuvo principio la nacionalidad gallega. ${ }^{41}$
\end{abstract}

Aparte de las grandes obras de síntesis escritas por Vicetto, Murguía o Risco hubo $\mathrm{y}$ hay mandatarios nacionalistas que sin unas pretensiones tan amplias, pretendieron dar su visión sobre el pasado gallego. Uno de ellos es Camilo Nogueira, que dedicó parte de sus esfuerzos intelectuales a escribir libros que giraron básicamente en torno a temáticas históricas. Nogueira destacó como uno de los mandatarios más notorios del nacionalismo gallego durante el último tercio del siglo XX y comienzos del XXI dentro de las filas del Bloque Nacionalista Galego (BNG), llegando a ser diputado en el parlamento gallego y eurodiputado en el parlamento europeo. Nos centraremos ahora en su libro A memoria da nación. O reino de Gallaecia y, más particularmente, en la visión que propone del reino suevo porque creemos puede resultar de interés para extender la interpretación tanto de la monarquía sueva como de la historia de Galicia en general hasta comienzos del siglo XXI y hacerlo, además, desde el punto de vista del

\footnotetext{
38 J. Beramendi, "Breogán en Numancia. Sobre los orígenes y peculiaridades del galleguismo decimonónico", en P. Anguera y otros, IIIes. Jornades de debat. Orígens i formació dels nacionalismes a Espanya (Reus: Centre de Lectura, 1994), 104.

39 J.C. Bermejo Barrera, ¿Para que serve?, 21.

${ }^{40}$ R. Máiz, O pensamento político de Murguía (Vigo: Xerais, 1999), 48.

${ }^{41}$ M. Murguía, Historia de Galicia, vol. 3 (Coruña: Librería de D. Andrés Martínez, 1888), 167-168.
} 
nacionalismo político. Reconocemos nuestra extrañeza ante el silencio de los historiadores gallegos en este punto ya que, entre otras cuestiones, la obra de Nogueira pone en tela de juicio, como veremos, su honestidad como profesionales. Nosotros sí analizaremos el contenido de este libro, no vaya a ser que nuestro silencio vaya a entenderse como conformidad hacia lo que Nogueira escribe.

Pero antes de tratar lo que tiene que ver con el periodo que nos interesa, consideramos necesario dedicar unas palabras al objetivo que persigue el libro de Nogueira y a la perspectiva que el autor tiene de la historiografía española. El propósito de la obra se pone de manifiesto desde la primera página: "A recuperación da memoria precisa, nomeadamente, dunha análise crítica da ideoloxía estatal española, que desvirtúa a realidade do pasado común aos pobos peninsulares e lle dá un carácter determinista á existencia do propio Estado na súa forma actual". ${ }^{42} \mathrm{Si}$ es precisa una recuperación de la memoria es porque esta se perdió en algún momento y por alguna razón. Es más, incluso podría existir un culpable, un responsable de que esa memoria esté perdida. En efecto lo hay y son los historiadores. La culpa no recae sobre los historiadores gallegos, sino sobre los españoles. No en vano, la historiografía española estaría aun dominada, según Nogueira, por el pensamiento de Ramón Menéndez Pidal y algunos de sus más destacados epígonos, entre los que destacaría uno de los mejores filósofos españoles, José Ortega y Gasset. Esta historiografía, además, estaría "estruturada a través dunha profunda e opaca masa de argumentos e estratos históricos perturbadores e sometida a un prexuízo contrario á diversidade das nacións peninsulares". 43

\footnotetext{
${ }^{42}$ C. Nogueira, A memoria da nación. O reino de Gallaecia (Vigo: Edicións Xerais de Galicia, 2001), 9. En realidad son las mismas tesis que plasmó en otro libro, cuyo título es bastante explícito: "A visión historiográfica que se impón corresponde á continuidade do ser de España desde tempo romano, se non antes, que foi instrumentada no século XIX. Dáse por indiscutíbel e intocábel a lectura castelanista do medievo [... ] Nese discurso Galiza non aparece máis que para ser negada. Para o pensamento oficial sería perturbador o recoñecemento das institucións medievais galegas e do sometemento político do reino no final do século XV, coa consecuencia da marxinación social e económica e dunha negación lingüísticocultural que durou cinco séculos", Para unha crítica do españolismo (Vigo: Edicións Xerais de Galicia, 2012), 150-152.

${ }^{43}$ C. Nogueira, A memoria, 10. De entre la inmensa bibliografía que abarca la idea de historiografía española recomendamos las siguientes lecturas. Sobre el proceso de construcción de la idea de España a través de la historia antigua, ver F. Wullf, La esencias patrias. Historiografía e historia antigua en la construcción de la identidad española (siglos XVI-XX) (Barcelona: Crítica, 2003). Sobre la evolución de la historiografía española, en la que tendrían un papel elemental las obras de Juan de Mariana, Modesto Lafuente, Rafael Altamira o el propio Ramón Menéndez Pidal, ver R. García Cárcel (coord.), La construcción de las historias de España (Madrid: Marcial Pons, 2004). Desde un punto de vista más teórico son básicos los trabajos de Bermejo, entre los que sugerimos, J.C. Bermejo Barrera y P.A. Piedras Monroy, Genealogía de la historia. Sobre el proceso de construcción de ciertos traidores, personajes y episodios en la construcción de la identidad española pueden verse los siguientes trabajos de un autor gallego que, en contra de la tendencia general que parece dominar nuestro saber, no concibe la historia como un cúmulo de prejuicios y mucho menos está a favor de oprimir la diversidad nacional de la Península a las que suele aludir Nogueira, pero sí de realizar una historia crítica, B. Padín Portela, "Un episodio en la construcción narrativa de la historia de España: los traidores y la "pérdida de España"', Historiografías, 11 (enero-junio 2016): 74-92; Id., "Héroes y traidores de la Antigüedad: dos arquetipos narrativos en la historiografía nacionalista española", Hispania Antiqua, 41 (2017): 389-428; e Id., "De traidor al rey a héroe nacional: la figura de el Cid en la historiografía española", Initium, 22 (2017): 309352.
} 
Nogueira reconoce la existencia de una ideología oficial que no puede admitir el papel central de Gallaecia porque eso implicaría invalidar una parte sustancial de los mitos que la sostienen. Pone el ejemplo de Claudio Sánchez-Albornoz, uno de los más importantes medievalistas españoles, exiliado en Argentina tras el estallido de la guerra civil, donde desempeñaría buena parte de su carrera académica. Resulta cuando menos contradictorio que Nogueira critique que una ideología oficial emplee sus mitos cuando él contribuye a mantener el mito de la monarquía sueva independiente en la historia de Galicia. Admite Nogueira, asimismo, la existencia de una historiografía castellanista, que contaría con una tradición secular, todavía hoy vigente, que se basaría en un relato histórico negador de los contenidos sustanciales de las mismas fuentes que utiliza, y que interpretaría la construcción del Estado español desde posiciones deterministas y uniformistas contrarias a la diversidad real. ${ }^{44}$

Tras esta serie de afirmaciones que podrían responder más bien a ciertos prejuicios que a la lectura atenta de los libros de algunos de los especialistas más relevantes de la historiografía gallega y española de los últimos años, estimamos apropiado realizar algunas observaciones porque lo que Nogueira dice es incorrecto en varios extremos. En primer lugar, conviene matizar que ni es medievalista ni tiene ninguna formación como historiador, sino que es un ingeniero que se dedicó también durante varias décadas a la política. Quizás en otros trabajos de investigación no sea necesario, pero en los de esta naturaleza puede ser aconsejable manifestar la precaución de que lo aquí analizado pertenece, como diría Platón, al mundo de las ideas y no al mundo sensible, por lo que no guarda ninguna relación con la figura política y por supuesto personal que Nogueira representa y que naturalmente respetamos.

En segundo lugar, contribuye Nogueira a sembrar una especie de duda sobre la honorabilidad y la dignidad de la labor de los historiadores en España, tarea que ya de por sí está cayendo cada vez en un mayor descrédito sin que los profesionales de la historia sepan muy bien lo que deben hacer para revertir dicha situación. Tal tesis se antoja poco fidedigna porque, a pesar de los problemas que desde hace varios años haya podido atravesar la disciplina histórica, consideramos que los intereses científicos siguen primando sobre los prejuicios ideológicos e imponiéndose a ellos. Ahora bien, no se puede negar que en el proceso de elaboración de una obra histórica un autor está condicionado por sus propias características personales y psicológicas, así como por sus circunstancias académicas, políticas y sociales, pero de ahí a asegurar que existe una conspiración historiográfica contra Galicia hay una distancia demasiado larga. Ello no quiere decir que aceptemos sin más el contenido de cualquier libro, al contrario, nadie se encuentra en posesión de la verdad absoluta y por eso suele ser común que en el mundo académico se discuta, pero esgrimiendo normalmente argumentos.

Por último, se establece, de acuerdo con el pensamiento de Nogueira, una dinámica que responde básicamente a la lógica de historiadores buenos e historiadores malos, que es a su vez el mismo arquetipo que se emplea para explicar el discurso histórico gallego. Es decir, nosotros, los gallegos, seríamos los buenos y los que no tenemos prejuicios, mientras que ellos, los españoles, serían los reaccionarios, representantes del Estado opresor que no permite la independencia de Galicia, el País

${ }^{44}$ C. Nogueira, A memoria, 21 y 24. 
Vasco y Cataluña, que, por supuesto, estarían caracterizados por siglos de opresión. Trasladado al campo historiográfico esta antítesis es, como hemos dicho, una constante. De hecho, la injusticia y el atraso, ya sea a nivel económico, social o político, serán explicados en base a esta interpretación que postula la existencia, en definitiva, de una patria y una antipatria.

Ahora bien, ¿desde dónde escribe Nogueira? Que el uso del lenguaje, que implica tanto la manera como la materia del discurso, depende de la posición social del locutor es algo que Pierre Bourdieu puso de manifiesto hace ya algún tiempo. ${ }^{45}$ La mayor parte de las condiciones necesarias para que un enunciado performativo tenga éxito se reducen a la adecuación del locutor, o, lo que es lo mismo, cuando los locutores no poseen la autoridad para emitir las palabras que enuncian, el enunciado performativo está condenado siempre al fracaso. La eficacia simbólica de las palabras se ejerce en la medida en que quienes la experimentan reconocen que quien la ejerce está autorizado para ejercerla. ${ }^{46}$ La autoridad de Nogueira viene dada porque su figura tiene una gran relevancia y prestigio en un contexto determinado, que es el del nacionalismo gallego de la segunda mitad del siglo XX y comienzos del XXI.

$\mathrm{Si}$ ahora nos remitimos al relato que proporciona Nogueira en relación con el periodo suevo, veremos que comienza diciendo que "a Gallaecia galaico-sueva mantivo unha entidade política diferenciada aínda despois do ano 585", lo que conllevaría implícitamente la visibilidad de esa identidad en época sueva e incluso con anterioridad a ella. Lo curioso es que Nogueira critique que la historiografía "españolista", de la que habíamos dicho que Menéndez Pidal era el mayor representante, cuando él utiliza un procedimiento similar: sostener la permanencia de una realidad secular que sería Galicia. Es un anacronismo entender a Viriato como un libertador de España contra el yugo romano, o que los saguntinos fueron mártires que prefirieron morir a vivir como esclavos bajo la dominación cartaginesa; pero también lo es afirmar que Gallaecia constituyó una entidad política diferenciada desde época sueva, porque durante el periodo que este pueblo germano se instaló en sus fronteras desconocemos incluso su propia existencia.

Decíamos al referir el episodio del Medulio que la correcta lectura hermenéutica es esencial para distinguir los intereses y las visiones que se esconden detrás de lo que escriben los autores clásicos. Pero es que la reconstrucción del pasado depende, también, de nuestras visiones apriorísticas que derivan, en palabras de Bermejo, de nuestras concepciones antropológicas y sociológicas, cuando no también de nuestros prejuicios y de nuestras ideas morales. ${ }^{47}$ No pretendemos erigirnos en impugnadores de la realidad sueva como el jesuita Juan Francisco Masdeu había hecho al negar la biografía del Cid, pero es cierto, como ha indicado P.C. Díaz, que si dependiésemos de la arqueología los suevos habrían sido un pueblo invisible, en otras palabras, no hay objetos específicos identificables, ni hay necrópolis asociadas con lugares de habitación que nos permitan detectar su presencia. Ni siquiera podríamos decir si se instalaron en las ciudades o en el campo, si eligieron lugares de control estratégico o si se mezclaron

\footnotetext{
${ }_{45}^{45}$ P. Bourdieu, ¿Qué significa hablar? Economía de los intercambios lingüísticos (Madrid: Akal, 1985).

${ }^{46}$ Ibid., 71-73.

${ }^{47}$ J.C. Bermejo Barrera, ¿Qué es la historia teórica? (Madrid: Akal, 2004), 113.
} 
con la población local. ${ }^{48}$ En lo que no nos equivocaríamos sería en afirmar que desde el punto de vista arqueológico los suevos no existieron. Es por ello que la importancia de la crítica histórica debería ser, si cabe, más acentuada en época sueva.

El recurso a las citas de la bibliografía consultada es un mecanismo frecuente para justificar los postulados de cualquier autor en el mundo académico. Es sorprendente que en la historiografía española exista algo interesante para Nogueira que no esté dominado por la conspiración contra Galicia. Es el caso de José Antonio Maravall, un historiador que contribuyó con trabajos decisivos en el ámbito de la Edad Media. ¿Por qué interesa Maravall? La respuesta es que cuando Nogueira trata de sostener la idea de una Gallaecia galaico-sueva diferenciada políticamente tras el año 585, alude a la noticia que da Juan de Biclara acerca de un concilio en Toledo en el que, como corrobora Maravall, habrían acudido los obispos "totius Hispaniae, Gallie et Gallecie". ${ }^{49}$ Da la impresión de que los autores españoles interesan dependiendo de la visión que ofrezcan sobre la historia de Galicia, es decir, si se trata de unos planteamientos válidos para Nogueira serán aceptados, mientras que si llegan a contradecir o a poner en cuestión las tesis defendidas en este libro o en el discurso que se pretende defender serán catalogados como historiadores incapaces de reconocer la nacionalidad específica de Galicia. En este sentido, Nogueira echa mano también de un reconocido medievalista representante de la Escuela de los Annales, el francés Jacques le Goff, a la hora de reconocer la no ocupación de Galicia por los musulmanes.

Lo que Nogueira pretende es, en definitiva, fundamentar la idea específica de Galicia. Intenta, pues, revestir este libro con un halo de historicidad y con una lectura hermenéutica de todo punto incorrecta. El reino suevo, en fin, pasa al imaginario colectivo, si combinamos las síntesis de la historia de Galicia con libros como el que nos presenta Nogueira, como un antecedente antiguo, puro y noble de independencia que sería de gran valor en el juego dialéctico establecido entre el nacionalismo gallego y el Estado español centralista.

Pero Nogueira no se encuentra solo a la hora de defender este discurso histórico. Creemos pertinente conocer ahora la visión que de la historia, al menos en lo que se refiere al reino suevo, tiene un partido político, el BNG, que incluso llegó a formar parte del gobierno gallego en coalición con el Partido dos Socialistas de Galicia (PSdG) durante la legislatura 2005-2009, más conocida como la del bipartito. En el preámbulo del proyecto para el Estatuto de Galiza, el BNG sostenía que los trazos que configuran la idea de la nación gallega se habían ido definiendo ya durante la Edad Media. Dentro de este contexto los suevos jugarían un papel elemental porque desde esa época, de la que, recordemos, no conocemos nada que no provenga de las fuentes literarias, Galicia se hallaría políticamente conformada: "A chegada dos suevos consolidou o marco político dun Reino de Galiza que, mediado o século VI, xa se apreciaba constituido". 50

Los ejemplos no se quedan ahí. Si revisamos su página web oficial veremos que en el Boletín Internacional con fecha de septiembre de 2014 se puede leer: "O Reino da

\footnotetext{
${ }^{48}$ P.C. Díaz, El reino suevo, 157.

${ }^{49}$ C. Nogueira, A memoria, 114.

50 http://www.bng.gal/media/bnggaliza/files/2012/05/10/Proxecto_Estatuto_Galiza.pdf [consulta 10 diciembre, 2018].
} 
Galiza é o primeiro reino que se constitui na Península, da mão dos suevos, antes ainda da desaparição do Império romano, no ano 411. Desenvolve uma vida independente e de enorme impulso político e cultural no contexto peninsular ao longo da Idade Media". ${ }^{1}$ No es necesario repetir que este tipo de afirmaciones suponen un anacronismo que no es posible aceptar desde el punto de vista histórico. La narración no varía con respecto a lo que los historiadores del siglo XIX proponían. Esas lecturas tienen todavía, sin embargo, cierta influencia en ámbitos nacionalistas que necesitan justificar la antiguiedad y la pervivencia de estructuras político-sociales de las que los gallegos de hoy en día serían todavía herederos.

El hecho de que Nogueira y partidos políticos como el BNG ofrezcan esta visión de la monarquía sueva y de la historia de Galicia, así como su mantenimiento en el tiempo puede estar motivado por tres razones. En primer lugar por determinados intereses que llevan a presentar un relato específico de la historia de Galicia y su relación con España con tintes claramente nacionalistas. En segundo lugar, por el silencio cómplice de los historiadores, particularmente los gallegos, que, por diversas motivaciones, todas ellas legítimas, no desean enfrentarse a esos postulados o a las personas y organizaciones que las defienden. Formalizan de ese modo la traición al saber histórico y su entrega absoluta al monumentalismo y al anticuarismo que tanto denunció Friedrich Nietzsche en la segunda mitad del siglo XIX, y, por otro lado, contribuyen a que la historia, en lugar de ser el saber crítico que se debería promover desde la universidad, pase a ser de nuevo aquel viejo género literario lleno de fábulas y leyendas propio de la Edad Media. Por último, y en el mejor de los casos, esta visión podría ser fruto del desconocimiento. Preferimos inclinarnos por la esta última ya que hacerlo por las dos primeras equivaldría a incumplir aquellos simples preceptos que sabiamente nos daba Luciano de Samosata al comienzo de este trabajo, tanto a los historiadores como a aquellos que quisieron jugar a serlo.

Johan Huizinga, un historiador holandés que desempeñó su labor en la primera mitad del siglo XX, llamó la atención sobre esta aparente capacidad y autoridad que personas sin formación histórica se arrogan para hablar sobre cuestiones de esa naturaleza. Caminamos por estos senderos hacia la definitiva banalización y trivialización de un saber histórico ya de por sí bastante falto de referentes. Por ello creemos útil concluir con estas palabras de Huizinga que reflejan perfectamente la situación que estamos viviendo:

No hay ninguna ciencia que tenga sus puertas tan abiertas al gran público como las tiene la Historia. En ninguna otra es tan fluctuante como en ésta la transición del diletante al especialista. En ningún otro campo se exigen tan pocos conocimientos previos de carácter científico como para comprender un trabajo de historia o para escribirlo. ${ }^{52}$

\section{Los antagonistas: Castilla y España.}

Hasta ahora se ha dibujado una relación de lucha constante en la que Galicia logra mantenerse independiente. Pero se da una paradoja, y es que tras un pasado

\footnotetext{
${ }^{51} \mathrm{http}: / / w w w . b n g . g a l / m e d i a /$ bnggaliza/files/2015/03/04//Internacional-1-por.pdf [consulta 10 diciembre, $2018]$.

${ }^{52}$ J. Huizinga, El concepto de la historia y otros ensayos (México: FCE, 1964), 36-37.
} 
enormemente glorioso se pasa a un presente de humillación. Es lógico pensar que en ese camino algo o alguien debió truncar la buena fortuna que el ser nacional estaba llamado a seguir desarrollando. La siguiente cuestión que nos deberíamos plantear sería, en consecuencia, qué o quién fue el responsable de que se llegara a una situación de postergación y opresión evidente, según se ve en las historias de Galicia. En otras palabras, hay que conocer cuál ha sido el origen del mal.

Bermejo planteó ya que la historiografía gallega es la obra de autores que desde el siglo XVI parecen ser conscientes de un sentimiento de inferioridad que derivaría, precisamente, o bien de esa situación injusta de opresión o de la marginación con respecto a otros reinos peninsulares. ${ }^{53}$ Por ejemplo, con respecto al mundo antiguo, como hemos visto, se verá la voluntad de intentar negar en la medida de lo posible cualquier tipo de romanización de la raza céltica, la cual lograría mantenerse pura. La lógica siempre se dará, como ha indicado Bermejo, en términos de dentro/fuera, nosotros/ellos, intentando asociar lo bueno y lo noble con el "nosotros" y lo malo y lo perjudicial con el "ellos". ${ }^{4}$ Esta dinámica se debe, en parte, al modelo fuertemente historicista según el cual la historia es la historia de una nación y de un pueblo que se enfrente a otros pueblos y naciones, que se impuso en España de la mano del proceso de la institucionalización de la disciplina histórica en el siglo XIX ${ }^{55}$ En el caso gallego si hay un antagonista arquetípico que dominará esta dialéctica será siempre Castilla y después España.

La derrota de los antepasados suele deberse a la invasión de un pueblo. Estos conquistadores tendrán una especial querencia por las riquezas naturales gallegas. Pero también en el ámbito historiográfico había agresiones castellanas. Llama la atención que Verea y Aguiar denuncie que el padre Juan de Mariana maltrate a Galicia "diciendo que es pobre" y que lo haga, por si fuese poco, escribiendo "una historia general, sin tener datos claros de los pueblos y países sobre los que habla", y en la primera página de su Historia de Galicia afirme lo siguiente:

\begin{abstract}
Una señal, y una parte del amor á la patria es el deseo, y el estudio de hallar la antigüedad gloriosa en la nacion ó pueblo á que se pertenece: tan natural esto como lo es en las familias el placer de descubrir una genealogía ilustre mas y mas remota. Los historiadores de todas las naciones se aprovechan de cuanto las es favorable para ennoblecerlas y ensalzarlas desde la misma cuna. ${ }^{56}$
\end{abstract}

Beramendi incidió en que el referente de negación-oposición vendría a constituir la mayor novedad teórica de la fase nacionalista en lo que atañe al concepto de Galicia. ${ }^{57}$ Esta idea consistiría en definir quién era el "Otro nacional" al que enfrentarse, pregunta ante la cual solo cabían dos alternativas. Por un lado se podía negar la Españanación y concebirla como un Estado formado por varias naciones, de las que una era dominante y a la vez opresor de las demás. Por el otro, seguir aceptando que España era

\footnotetext{
${ }^{53}$ J.C. Bermejo Barrera, "Los antepasados imaginarios", 85.

${ }^{54}$ J.C. Bermejo Barrera, ¿Para que serve?, 20.

55 Ibid., 22.

${ }^{56}$ J. Verea y Aguiar, Historia de Galicia, vol. 1 (Ferrol: Imprenta de D. Nicasio Taxonera, 1838), 1-2.

57 J. Beramendi, De provincia a nación. Historia del galleguismo político (Vigo: Edicións Xerais de Galicia, 2007), 574.
} 
una nación pero que Galicia también lo era, pasando de este modo España a ser automáticamente otra nación que mantenía sometida y anexionada a la gallega. ${ }^{58}$

Castelao popularizó la idea de la "doma e castración do reino de Galiza" en su Sempre en Galiza, siendo el autor que más contundentemente defendió el referente de negación. Dice Castelao que los Reyes Católicos "venceron e aferrollaron a Galiza, e que a política centralizadora produxo un esvaimento da nosa persoalidade, reducindo a nosa lingoa culta a unha lingoa rústica", pero "apta para calquera renascencia cultural". ${ }^{59}$ Castilla logra someter a Galicia de modo que logró que "durante tres séculos consecutivos non se produxese na Galiza - como na Cataluña- ficou muda", ${ }^{60}$ en clara alusión a los conocidos "séculos escuros". Según Castelao, no era posible la emancipación del pueblo gallego porque "Galiza caía en escravitude, gobernada i esplotada por estranxeiros. O noso povo foi vítima do maquiavelismo castelán, pois era capaz de levantarse contra os seus señores i endexamáis pudo sacudir o xugo que él mesmo axudou a someter â súa patria". 61 La imagen que trasciende el tiempo acerca de los Reyes Católicos y que cambia de protagonistas en dependencia de los tiempos es, en esencia, la que autores como Murguía, Brañas o Castelao proyectaron.

De acuerdo con esta concepción de la historia de Galicia que se mantiene durante el siglo XIX y buena parte del XX, no existirían traidores o, de haberlos, su influencia sería nula. Esto se debe a que todas las agresiones vienen de fuera y por lo tanto no son necesarios. En todo caso, el traidor debería ser aquella nobleza laica a la que se refería Murguía y que era responsable de la explotación de las clases inferiores y de que Galicia no alcanzase la independencia. Desde luego, el papel del traidor en la historiografía gallega está muy alejado del que desempeñó en la española, donde como es bien sabido ocupó un lugar preeminente en episodios tan notorios como la "pérdida de España" o en muertes tan significativas en el mundo antiguo como las de Sertorio y Viriato, por poner solo algunos ejemplos.

Xosé Ramón Barreiro demostró en varios trabajos que Castilla se convierte en el mayor enemigo de Galicia a partir de la publicación de los Cantares Gallegos de Rosalía de Castro en el año $1863 .{ }^{62}$ Recordemos aquellos célebres versos que influyeron notoriamente a la hora de crear esta imagen y que decían: "Castellanos de Castilla, tratade ben ós gallegos; cando van, van como rosas; cando vén, vén como negros [...] Van probes e tornan probes, van sans e tornan enfermos, que anque eles son como rosas, tratádelos como negros". Serían las Irmandades da Fala en el primer cuarto del siglo XX, de acuerdo con Barreiro, las que convertirían la composición poética de Rosalía "nunha bandeira ideolóxica de acción política". ${ }^{3}$

\footnotetext{
${ }^{58}$ Ibid., 575.

${ }^{59}$ A. Castelao, Sempre en Galiza, 67.

${ }^{60}$ Ibid., 103.

${ }^{61}$ Ibid., 371-373.

${ }^{62}$ X.R. Barreiro Fernández, "El mito del anticastellanismo en Galicia”, en L. Fernández (coord.), Castilla y España (Valladolid: Universidad de Valladolid, 2000), 89-117, e Id., "Galicia e Castela: orixe, evolución e fracaso do mito anticastelán”, en H. González, y $\mathrm{M}^{\mathrm{a}} \mathrm{X}$. Lama (coords.), Actas VII Congreso Internacional de Estudos Galegos: mulleres en Galicia. Galicia e os outros pobos da Península, Barcelona 28 ó 31 de maio de 2003, vol. 1 (Barcelona: Universitat de Barcelona, 2007), 25-38.

${ }^{63}$ X.R. Barreiro, "Galicia e Castela", 36.
} 
En el discurso político actual de tendencia nacionalista esta idea según la cual Galicia es un paraíso lleno de recursos naturales que le son usurpados sigue utilizándose profusamente. Se denuncia que Galicia sufre un expolio imparable de sus materias primas, sobre todo por parte de Madrid, que sigue creyendo que Galicia no es más que su colonia. Entre los ámbitos más destacados en que se produce ese expolio se encuentran la pesca, la agricultura o la energía.

Xosé Manuel Beiras Torrado, el intelectual más destacado del nacionalismo gallego de los últimos cincuenta años, escribió un libro a comienzos de los años setenta del siglo pasado, $O$ atraso económico de Galicia, que se convirtió en un clásico. ${ }^{64}$ Beiras desempeñó su carrera académica como catedrático de Estructura Económica de la universidad compostelana y empleó el concepto de colonia interior, tomado de un autor de origen francés, Robert Lafont, que había hecho un estudio acerca de ese fenómeno en Francia, y lo trasladó a la historia de Galicia. La clave es la siguiente: Galicia es una economía subdesarrollada que se encuentra en la periferia del sistema a pesar de situarse en la propia Península, y en virtud de su riqueza es sometida a un expolio sistemático. Los resortes de la dependencia colonial, según Beiras, vendrían dados por el hecho de que la economía dominada no dispondría de herramientas que lograsen defender su frontera política y arancelaria, ya que la economía dominante dispondría de una gran capacidad de presión sobre el Estado y la economía dominada. Esta relación siempre desigual se expresaría a través de dos mecanismos, el bloqueo y la desposesión de los intereses autóctonos.

Los colonizadores no solo expolian los recursos sino también la fuerza de trabajo, estableciéndose de ese modo un vínculo triangular en este proceso, con los vértices en la sociedad precapitalista y en el sector moderno de la economía gallega, por un lado, y, por el otro, en los centros de poder económico españoles. Esta visión, cuya asunción por parte del nacionalismo gallego actual es inequívoco, no puede sostenerse por más tiempo. Las referencias a este respecto que podríamos enumerar son ciertamente extensas, pero no creemos necesario porque queda de manifiesto en estas páginas que el discurso defendido es el mismo y, además, intentar explicar los problemas económicos de Galicia en base al expolio español es incorrecto en un mundo ya descolonizado y que, desde el punto de vista económico, atiende a unos intereses financieros muy alejados de este tipo de lógicas.

\section{Los mártires}

La función que se les tiene reservada a los mártires en cualquier nacionalismo es ejemplarizante. No en vano, al hablar de mártir estamos haciendo referencia a aquellos que prefirieron dar sus vidas por una causa común convirtiéndose, junto con los héroes, en los verdaderos arquetipos de conducta que todo ciudadano debe imitar. El sacrificio al que son sometidos los mártires es la guía a seguir por cualquier buen patriota. La abnegada fe en que se basa su lucha suele ser su rasgo más relevante. Pueden morir por defender su religión, sus ideales o sus postulados políticos, pero su muerte va a ser siempre heroica e injusta por estar del lado de la libertad. Analizaremos ahora algunos de los mártires más significativos del nacionalismo gallego relacionándolos con el

${ }^{64}$ X.M. Beiras, O atraso económico de Galicia (Vigo: Xerais, 1972). 
discurso de las historias de Galicia y con los objetivos que se persiguen mediante la idealización de los mismos.

Tal vez haya sido Prisciliano, que vivió en la segunda mitad del siglo IX, el primero de los mártires que acabaría formando parte del ideario nacionalista gallego. El priscilianismo se caracterizó por ser un movimiento religioso de carácter ascético, basado en los ideales de austeridad y pobreza, que abogaba por abandonar las ciudades para recluirse en el campo o en retiros espirituales, teniendo siempre presente la idea de prescindir de lo material, por lo que propugnó la renuncia a los privilegios que disfrutaba el clero. En los once tratados priscilianistas conservados en un códice de la biblioteca de la Universidad de Würzburg, fechado hacia el siglo V-VI, se puede ver algo de su mensaje evangelizador.

Si seguimos el argumento propuesto por Chadwick, en algunas regiones de Hispania, sobre todo en Gallaecia, se celebró jubilosamente a Prisciliano como mártir. Afirma Chadwick que se realizaban juramentos solemnes en el santuario de Prisciliano, que parece haber estado situado en algún lugar de Gallaecia, a pesar de la falta de datos que suelen caracterizar épocas históricas como esta. ${ }^{65} \mathrm{Al}$ hablar de esta cuestión debemos tener en cuenta que en Gallaecia no había hasta ese momento reliquias, y sería lógico pensar que la llegada de los restos de los ejecutados en Tréveris, al frente de los cuales se erigía Prisciliano, desencadenaría una oleada de fervor popular. Sus seguidores lo consideraron mártir y el priscilianismo se prolongó en Hispania como un movimiento de reforma moral, al menos durante dos siglos, especialmente en el noroeste peninsular.

En la historiografía nacionalista gallega Prisciliano cumplió a la perfección el papel de mártir. En algunas de las historias de Galicia más importantes tanto Prisciliano como sus seguidores son presentados como una especie de reacción popular ante la imposición ajena del cristianismo, en lo que es un recurso habitual de la dialéctica dentro/fuera que domina el discurso histórico gallego. Hubo autores como Otero Pedrayo que defendieron firmemente la figura y el legado de Prisciliano, mientras que otros, como pudo ser el caso de Risco, mostraron una actitud menos apasionada, ya que, por ejemplo, en la descripción de la muerte del supuesto hereje se limita a decir que su decapitación se produjo junto a la de otros dos clérigos, Felicísimo y Armenio, un diácono, Aurelio, y tres poetas, Latroniano, Asarivo y Eucrocia. ${ }^{66}$

El nacionalismo gallego vio en Prisciliano un elemento de legitimación contra el invasor y lo ajeno, un símbolo de Galicia. Pasó al panteón mitológico nacional como uno de los mártires más importantes, cuya memoria había que honrar. Compartió Prisciliano, además, la estructura narrativa que tendrán los siguientes mártires que trataremos: en estos arquetipos los mártires son asesinados injustamente pero sus ideales sobreviven y se toman como ejemplo de conducta que merece ser recordado, honrado y, sobre todo, imitado por las sucesivas generaciones de gallegos.

\footnotetext{
${ }^{65}$ El libro de referencia que sigue siendo esencial tanto en el tratamiento de la figura de Prisciliano como en la interpretación de su pensamiento es el de H. Chadwick, Prisciliano de Ávila. Ocultismo y poderes carismáticos en la Iglesia primitiva (Madrid: Espasa-Calpe, 1978).

${ }^{66}$ V. Risco, Historia de Galicia (Vigo: Galaxia, 1976), 62.
} 
Trataremos ahora, dentro de la panorámica de mártires utilizados por el nacionalismo gallego que queremos ofrecer, aquellos que protagonizaron el levantamiento de 1846, que suele ser considerado como el hito fundacional del galleguismo político. De hecho, es precisamente en esa década cuando nacerá el provincialismo gallego, extendiéndose hasta que en torno a la década de los ochenta del siglo XIX, mute en regionalismo. El 2 de abril, como es bien sabido, el comandante Miguel Solís, quien, por cierto, no era gallego sino de origen gaditano, se pronuncia en Lugo. Se formó rápidamente una Junta de Gobierno y el movimiento se extendió a Santiago y después a otras ciudades como Pontevedra o Vigo. El Gobierno envió tropas al mando del general Gutiérrez de la Concha, que derrotaría a Solís en las inmediaciones de Santiago. Solís acabó siendo fusilado con once de sus oficiales el 26 de abril en Carral.

El objetivo que perseguía el levantamiento no era liberarse del supuesto yugo opresor español. Barreiro enumeró dos niveles diferentes en los objetivos que se perseguían con el levantamiento: los económicos y los políticos. ${ }^{67}$ En cuanto a los primeros, habría que señalar que tanto en las proclamas de las Juntas como en los bandos de los ayuntamientos se alude a la injusticia del nuevo sistema tributario y a la necesidad acuciante de suprimirlo, aunque realmente no parece que el nuevo sistema tributario gravase mucho más a la población agravando de ese modo la situación económica. Desde el punto de vista político y atendiendo a los bandos, oficios, periódicos y demás documentación conservada, el objetivo consistiría esencialmente en cambiar el Gobierno y, sobre todo, hacer caer a Narváez. Esto no quiere decir que se pretendiese un cambio de régimen. En efecto, no hay mención de ninguna medida descentralizadora y ni siquiera se pone en cuestión la división provincial elaborada por Javier de Burgos en 1833.

Las resonancias históricas de este episodio traspasaron ampliamente el siglo XIX. En contra de lo que pudiésemos pensar este mito goza de una total pervivencia en determinados ámbitos. Una manera de conocer la continuidad de ciertos tópicos historiográficos en el nacionalismo gallego consiste en dirigirnos a los presupuestos históricos que defienden partidos de ese signo. Veamos, entonces, cómo el BNG vuelve a echar mano anacrónicamente de otro tópico como el del levantamiento de 1846 y los mártires de Carral con unos fines puramente reivindicativos. Debe ir por delante que tal y como hemos dicho al referirnos a Nogueira, aquí no aludiremos en ningún momento al papel desarrollado por el BNG desde el punto de vista político ni a las personas que de esta organización forman parte, sino que simplemente estamos analizando la presencia de ciertos lugares comunes en el nacionalismo gallego de los últimos cincuenta años, que es en sus líneas generales el que encarna el BNG.

En la página web oficial de este partido político podemos ver la organización, promovida por el propio BNG, de un acto cuyo objetivo sería mostrar la vinculación de los mártires de Carral con el nacimiento del nacionalismo y con Santiago de Compostela. Se trata de un texto publicado en abril de 2017, y llama la atención que se finalice el artículo haciendo referencia a otra intención que perseguiría este acto, que sería la de "recuperar a memoria do pobo galego, co fin de proxectar no presente o

\footnotetext{
${ }^{67}$ X.R. Barreiro, El levantamiento de 1846 y el nacimiento del galleguismo (Santiago de Compostela: Pico Sacro, 1977), 203-229.
} 
heroísmo, a dignidade e o sacrificio de pasadas xeracións que deron a súa vida á causa da liberación nacional de Galiza" ${ }^{68}$ Este acto, que se repite anualmente, puede ser utilizado también para comparar la situación vivida hace más de ciento cincuenta años con la actual. Por ejemplo, la concentración de 2014 pretendía reivindicar "a loita de todos os precursores do nacionalismo galego en defensa de Galiza, a supervivencia deste país fronte ao centralismo", ya que "entendían que era a mellor maneira de defender a nosa identidade, a economía produtiva do país fronte á voracidade do centralismo madrileño". ${ }^{69}$ Aquí se añade otro elemento, que es el del enemigo exterior, identificado, como no podía ser de otra manera, con Madrid, identificándola con la base de todos los males de Galicia. Por otro lado, en un semanario gallego, Sermos Galiza, se recoge que en el año 2015, con la tradicional concentración celebrada ante el monumento dedicado a los mártires, defensores de una "maior autonomía para este país e plantaron cara ás políticas da corte contra Galiza, algo que segue a ter plena vixencia na actualidade". Se añade que hoy en día sigue siendo necesario luchar contra el expolio al que Galicia se ve sometida a través de las políticas "recentralizadoras que arrasan o tecido produtivo e que levan a ruína o país". Es necesario, por ello, recuperar las reivindicaciones de los comandados por Solís, que en ningún caso coinciden con las que pregona el BNG. En realidad, que las reclamaciones sean diferentes no importa, por ello este partido político no duda en admitir que Galicia se había convertido en una "colonia da Corte española", ${ }^{70} \mathrm{y}$, en su página web, en el apartado "Principios políticos", se vuelve de nuevo al viejo tópico de la incapacidad de progresar de Galicia: "O nacionalismo galego é a resposta democrática do noso pobo ante unha situación de dependencia económica, de opresión cultural e política da Galiza que imposibilita o progreso e benestar da sociedade galega". ${ }^{71}$

¿Por qué es útil realizar esta determinada lectura del acontecimiento de 1846? La respuesta es sencilla. Si admitimos que el levantamiento fue uno más estaríamos limitando tanto la significación como la influencia de lo que algunos consideraron el hito del que surgiría el galleguismo. Se ignora, no sabemos si voluntariamente, la visión historiográfica más extendida, que consiste en entender, más allá del apasionamiento nacionalista que en ciertos momentos dominó este episodio, el levantamiento de 1846 como un pronunciamiento más de los muchos que hubo en el siglo XIX español. Pero que esta visión se siga defendiendo hoy en día puede responder, más bien, a dos razones: al desconocimiento que de la bibliografía básica sobre el tema se pueda tener o a ciertos intereses políticos. En efecto, entre las estrategias políticas del BNG se sitúa la reivindicación de la memoria de los mártires de Carral como libertadores de la patria gallega ante la opresión española. Es lógico que las formaciones políticas defiendan aquellas cuestiones en las que creen, pero lo que no se debe hacer es reescribir la historia, falseándola, y ponerla al servicio del ideario de ningún partido.

\footnotetext{
${ }^{68} \mathrm{http}$ ://santiago.bng.gal/articulo/novas/acto-martires-carral-sua-vinculacioncoacidade/20170424143626001843.html [consulta 10 diciembre, 2018].

69 http://www.bng.gal/articulo/destacadas/loita-martires-carral-vixente-recentralizacion-do-pp-devoranoso-autogoberno/20140426164737011434.html [consulta 10 diciembre, 2018].

70 http://www.sermosgaliza.gal/articulo/memoria/bng-reivindica-vixencia-da-loita-soberanista-martirescarral/20150426211044036872.html [consulta 10 diciembre, 2018].

${ }^{71} \mathrm{http}: / / \mathrm{www}$. bng.gal/estaticas/principios-do-bng/ [consulta 10 diciembre, 2018].
} 
Por último, cabría mencionar que los mártires que existieron en el siglo $\mathrm{XX}$ respondieron a un mismo origen: la lucha contra el régimen franquista. Alexandre Bóveda, un intelectual al que Castelao dedica su Sempre en Galiza, significó probablemente el mártir más valioso para el nacionalismo gallego. Vinculado al Partido Galeguista, Bóveda terminó siendo fusilado por los sublevados al comienzo de la guerra civil en A Caeira, en las inmediaciones de Pontevedra, donde desempeñaba su actividad política y profesional como jefe de contabilidad de la Delegación de Hacienda.

El asesinato de Bóveda se reivindicó también desde las instituciones políticas. En 2005 se promovió la "Declaración institucional a respecto da memoria histórica e da rehabilitación moral, persoal e legal á figura de Alexandre Bóveda". ${ }^{72}$ La iniciativa partió del BNG, que en aquel momento ocupaba la vicepresidencia de la Xunta de Galicia. El texto exigía, por un lado, que la Xunta demandase del Estado la anulación del Consejo de Guerra que en juicio sumarísimo aprobó el fusilamiento de Bóveda y, en segundo lugar, el apoyo a las iniciativas que diesen a conocer la verdad histórica, la rehabilitación moral y pública de todas las víctimas gallegas de la represión de la dictadura, y, en general, la reparación de los daños morales y materiales. Galicia implementó medidas de este tipo antes que España, pues el año 2006 llegó a ser denominado formalmente por el Congreso de los Diputados el "Año de la Memoria Histórica”, en alusión a los múltiples actos que desde el ejecutivo se promovieron para homenajear y recordar a las víctimas de la guerra civil y el franquismo.

Decía el historiador y filósofo italiano Benedetto Croce que toda historia es historia contemporánea. Se refería Croce con esta máxima a que suele ser el presente el que otorga sentido al estudio y al conocimiento del pasado. Por ello se cree que se les pueden aplicar los mismos esquemas que tenemos en la actualidad al comportamiento de los que lucharon en el Medulio, a los irmandiños o a los que protagonizaron el levantamiento de 1846, cuando los condicionantes económicos, sociales, políticos o psicológicos no tienen nada que ver. Es en este contexto donde los mártires se emplean para explicar y justificar el presente, para atribuirles a ellos propósitos que solo guardan mucha relación con el mundo que nosotros habitamos ahora pero ninguna con el que ellos habitaron hace dos siglos o hace un milenio. Dicho procedimiento que no se realiza atendiendo a sus propias conductas o dinámicas históricas sino que se hace a través de las proyecciones que se realizan desde el momento en que vivimos.

En el final de Bóveda se entremezclan hechos tan simbólicos como pedir al tribunal "que me entierren envuelto en la bandera gallega. No por fuera de la caja, ya sé, sino por dentro nada más". ${ }^{73}$ Aunque quizás hayan sido las palabras que pronunció ante el tribunal cuando ya sabía el desenlace que le esperaba las que revelen el verdadero alcance del que todavía hoy es recordado como el mártir por antonomasia del nacionalismo gallego:

Mi Patria natural es Galicia. La amo fervorosamente. Jamás la traicionaría, aunque se me concediesen siglos para vivir. La adoro hasta más allá de mi muerte. Si entiende el Tribunal

\footnotetext{
72 http://www.xunta.gal/c/document_library/get_file?folderId=31610\&name=DLFE-1531.pdf [consulta 10 diciembre, 2018].

73 X. Álvarez Gallego, Vida, paixón e morte de Alexandre Bóveda (Buenos Aires: Edicións Nós, 1972), 262.
} 
que por este amor entrañable, debe serme aplicada la pena de muerte, la recibiré como un sacrificio más por ella. Hice cuanto pude por Galicia y haría más si pudiera. Si no puedo, hasta me gustaría morir por mi Patria. Bajo su bandera deseo ser enterrado, si el Tribunal, en conciencia, juzga que debo serlo. Y este 'agarimo' -permítaseme la única palabra gallega que empleo en el idioma que he hablado siempre- que le tengo a la Tierra Sagrada en que tuve la dicha de nacer, no me obliga a sentir ningún odio a España, a la que, por derecho, pertenezco. Solamente he combatido sus errores, y, a veces, sus crueldades políticas para con mi Galicia idolatrada. Nada más. ${ }^{74}$

\section{Conclusiones}

Cuando se intenta explicar con trazos gruesos la historia de cualquier país, sustentando el decurso histórico sobre fechas señaladamente significativas por ser fuertes episodios de reivindicación nacionalista, se corre el riesgo de caer en la trivialidad, la simpleza o el anacronismo. Si el único objetivo que se persigue con la historia es el de reconstruirla para de ese modo favorecer u obtener unos beneficios políticos o de cualquier otro tipo, la historia nos lleva al propio desconocimiento de nuestro pasado. En este sentido, de lo que se trata aquí es también de reivindicar un viejo anhelo que parece ser, más bien, una quimera, pues, si bien siempre se reclama es muy difícil de llevar a cabo. Nos estamos refiriendo a la necesidad de exigir un relato coherente y crítico de la historia, libre de manipulaciones.

El nacionalismo gallego va a necesitar siempre un opresor. Sin él su lucha y sus reivindicaciones perderían en gran medida su fuerza. Los Reyes Católicos, por ejemplo, son tan importantes porque van a marcar la formación definitiva de las tensiones con un sujeto ajeno y la definitiva disociación entre Castilla y Galicia. Este esquema víctima/opresor se irá perfilando, pero Galicia precisará de un antagonista, alguien que le impida ejercer su propia autonomía. Si Galicia lograse la independencia tendría la capacidad, según esta visión, de gestionar sus recursos o favorecer el empleo de su lengua y sus costumbres sin tener que dar cuentas ante España. El arquetipo narrativo que hemos tenido ocasión de analizar en estas páginas es a su vez un modelo muy útil que el nacionalismo gallego necesita que perviva, ya que si el enemigo desaparece Galicia habría cumplido su destino histórico y el nacionalismo político como impulsor de ese cambio carecería de sentido. En otras palabras, ya habría cumplido su trabajo.

Concluiremos este trabajo con una cita de Edward Gibbon, un historiador inglés del siglo XVIII, que José Álvarez Junco recoge al comienzo de su último libro, Dioses útiles. ${ }^{75}$ Creemos que esta referencia podría resumir en parte lo tratado en estas páginas. Decía Gibbon que los dioses en la antigua Roma eran verdaderos para la plebe, falsos para el filósofo y útiles para el político. Basta sustituir la palabra dioses por nacionalismo y comprobaremos que, en el fondo, dos mil años no son nada.

\footnotetext{
${ }^{74}$ Ibid., 229.

${ }^{75}$ J. Álvarez Junco, Dioses útiles. Naciones y nacionalismos (Barcelona: Galaxia Gutenberg, 2016).
} 


\section{Profile}

Bruno Padín Portela es doctor en Historia por la Universidad de Santiago de Compostela. Ha publicado artículos en revistas como Historiografías, Hispania Antiqua o Initium, analizando temas relacionados con la historiografía española.

Bruno Padín Portela has a PhD in History at the University of Santiago de Compostela. He has published articles in the journals Historiografías, Hispania Antiqua and Initium, analyzing topics related to spanish historiography.

Fecha de recepción: 24 de julio 2018.

Fecha de aceptación: 18 de noviembre de 2018.

Publicación: 31 de diciembre de 2018.

Para citar este artículo: Bruno Padín Portela, "El antagonista imprescindible: la construcción de la identidad nacional en la historiografía gallega", Historiografías, 16 (julio-diciembre, 2018): pp. 10-35. 